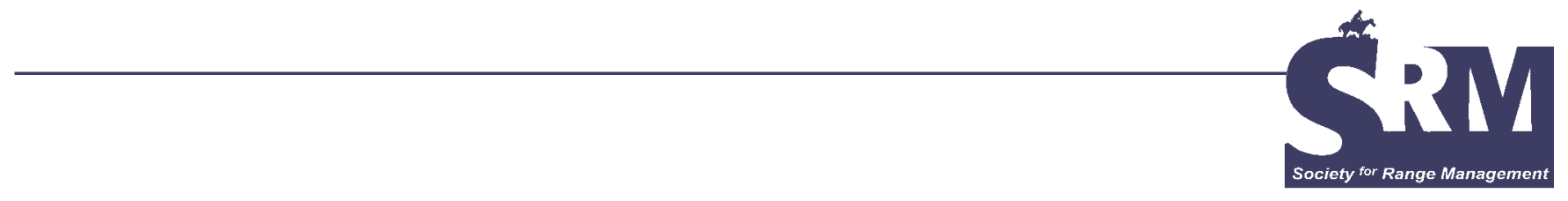

\title{
Evolving Views of Public Land Values and Management of Natural Resources
}

\section{By Thomas M. Quigley}

I

n 2005, the USDA Forest Service celebrates its 100th birthday. For a century, this agency has been charged with managing much of the Nation's forests and rangelands in the public interest. From its humble beginnings with a handful of employees and a clearly stated vision, today the agency's 35,000 employees are responsible for managing more than 190 million acres of national forests and grasslands, for directing one of the world's largest natural resources research agencies, for directing cooperative state and private forestry programs, and for overseeing an international forestry program. The Centennial provides an opportunity to reflect on changes that have occurred over the last century and a chance to consider where management of natural resources in the next century will head. One venue for discussions of Forest Service influence and management was a series of regional Centennial Forums and a Centennial Congress that convened in January 2005. At the Rocky Mountain Centennial Forum, range management and rangeland resources were specifically highlighted. This paper highlights the transitions that have occurred and looks to the future regarding rangeland and natural resource management, with specific emphasis on the role the Forest Service has played, and will play, in this process.

To undertake this examination, it is useful to consider how societal values, organizational values, and personal values have shaped the past and will continue to shape the future management of natural resources.

\section{Societal Values Shape Resource Management}

Management of natural resources, and especially the National Forests, is a reflection of society's values. Society's values are evidenced in the mix of laws, policies, budgets,

\section{Time and Tough Decisions Make a Difference}

As a forest ranger's son growing up in the 1950s, I spent considerable time with my Dad during the summer. I was there to help count the cattle and sheep in the forest, to fix fence, repair water troughs, set out the utilization cages, put allotment ear tags on cattle, empty the trash from campgrounds, and maintain guard stations. I witnessed large reductions in grazing by cattle and sheep during this time on the allotments my father oversaw. I recall it was not until I hit my teens that I came to realize that riparian areas could actually have vegetation in them at the end of a grazing season. I personally witnessed the gradual improvement in range conditions from the 1950s as I accompanied my Dad to the allotments; through the 1960s as a student in college; in the 1970s as an assistant Ranger, when I had responsibility to manage allotments; in the 1980s as a Range Scientist, working on one of the largest range research projects to be undertaken-the Oregon Range Evaluation Project; and into the 1990s and 2000s, as I have analyzed forest and rangeland conditions in the Columbia Basin. Today, it is my assessment that overgrazing is not the first, or even second, greatest threat to rangeland health. Invasive species, fire, and development now supercede grazing as the greatest threat.

appeals, lawsuits, migration patterns, resource demands, and the ways in which we use goods and services derived from federal lands. Many of the outcomes resulting from the full expression of these values are influenced by the perception of society's values that are held by Forest Service (FS) employees. For instance, policies, regulations, goals, targets, plans, 


\section{Science}

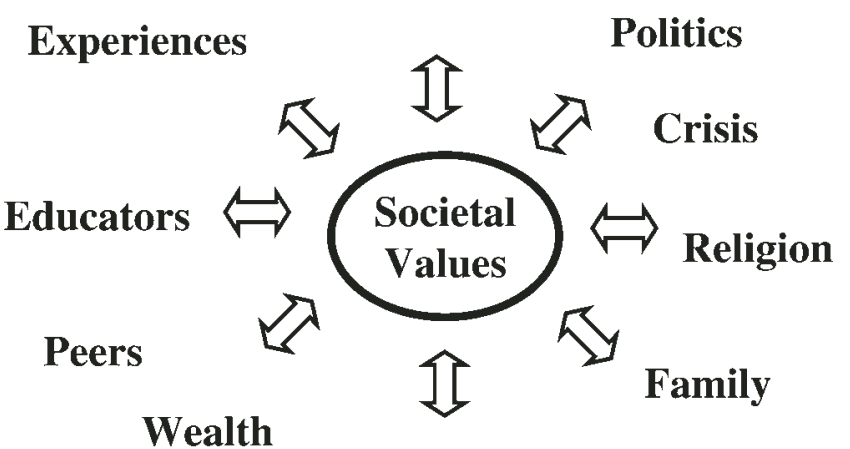

Media

Literature

Figure 1. Societal values are influenced directly or indirectly by a variety of elements.

and budgets related to natural resource management and use often have their beginnings rooted in choices made by FS managers, staff, and leaders. Thus, the perception of society's values held by FS employees, especially line officers, can be a useful gauge of likely shifts in resource management and use. If FS employees perceive that there is less societal interest in a particular resource or use, then policies, budgets, and management energy will flow away from that resource. These values, in turn, become ingrained within the culture of the Forest Service and reflected in the organizational values the agency proclaims and rewards.

Society's values play out in various ways, but invariably there is a time lag between the actual shift of values, the perception of those shifts by FS employees, and their expression via agency actions, policies, or laws. Not only is the lag a natural consequence of perceiving and acting, but the policy and legal framework within which change gets made in the United States has been purposely made a cumbersome process to prevent rapid shifts and swings. Getting a law through from conception to passage and implementation is, indeed, a slow process. So we should expect to find any agency operating within the statutes of law to always lag behind major shifts in public values.

Many of the changes that are witnessed on the ground are a reflection of how FS employees view social values. The perceptions held by FS employees reflect society's values and evolve as the workforce changes. One of the quickest feedback loops is in the appropriation process, in which shifts in funding can be made relatively quickly because of the need to fund agencies on an annual basis. Alternatively, the slowest feedback loops happen when major legislation is passed and signed into law.

Organizational values are a reflection of social values in that, if an agency gets out of synch with social values, it is likely there will be changes wrought on them by many sources, not the least of which are court mandates and Congressional appropriations.
It is useful to consider our personal values and the values of society as a portfolio. For instance, in the same way we think about a portfolio of financial investments, societal and personal values comprise many differing components. If we consider the traditional multiple uses of the Forest Service, namely wood, water, forage, wildlife, and recreation, an individual's portfolio of values would consist of separate values for each use. One person might place a relatively high value on rangeland forage for livestock use, whereas another might place a relatively high value on recreation. It does not mean that an individual sees no value in one of the multiple uses, only that there is a relative ranking among the values. If we had the ability to aggregate the individual values across society, we could display the results as a portfolio showing a summary that approximates the relative values for each of the multiple uses. That portfolio would reflect relative value differences, or rankings, among the uses. Just as the value of a financial portfolio changes, so do the individual values for each of the multiple uses change within any given portfolio.

Societal and personal values are influenced by a host of factors (Fig. 1). Individuals and groups within society respond differently to the factors that influence values. Some are strongly influenced by experiences and science information, whereas others are strongly influenced by family and religion. Although experience and science are important, they are not the only, and might not even be the most important, influences.

As individuals or groups gather evidence that shapes their values, the weight of evidence accumulates until it is large enough to determine that a shift has indeed happened. When the weight of evidence gets large enough, there are attempts by agencies to alter their policies, and Congress gets sufficiently motivated to change laws. The change in values can be in either direction, toward more (or less) emphasis on managing a particular resource. Society is not a uniform block of values that suddenly shifts to a new view. Rather, there is a distribution of values among the people. It might take some dramatic event, such as a large fire, major failure,

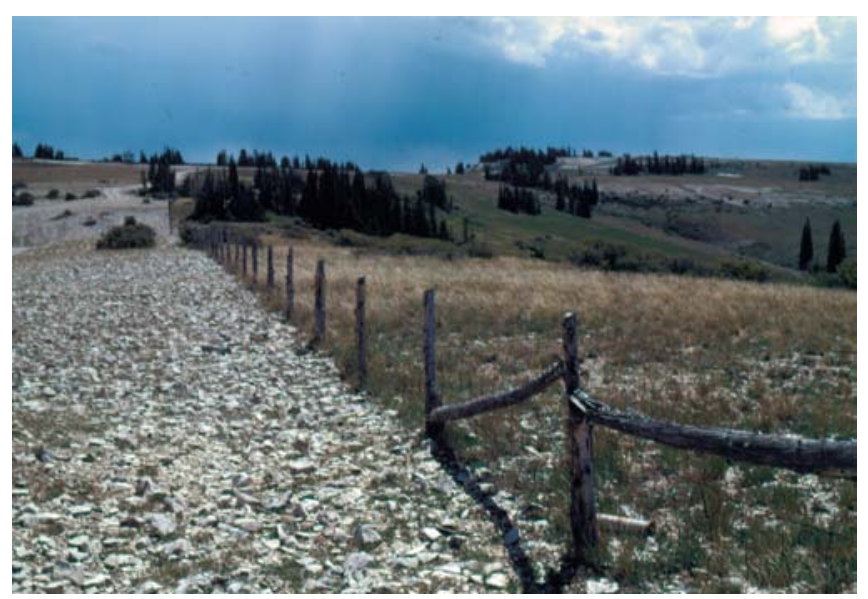

Some historic drive trails remain as evidence of heavy livestock use in the past. Photo courtesy of USDA Forest Service. 


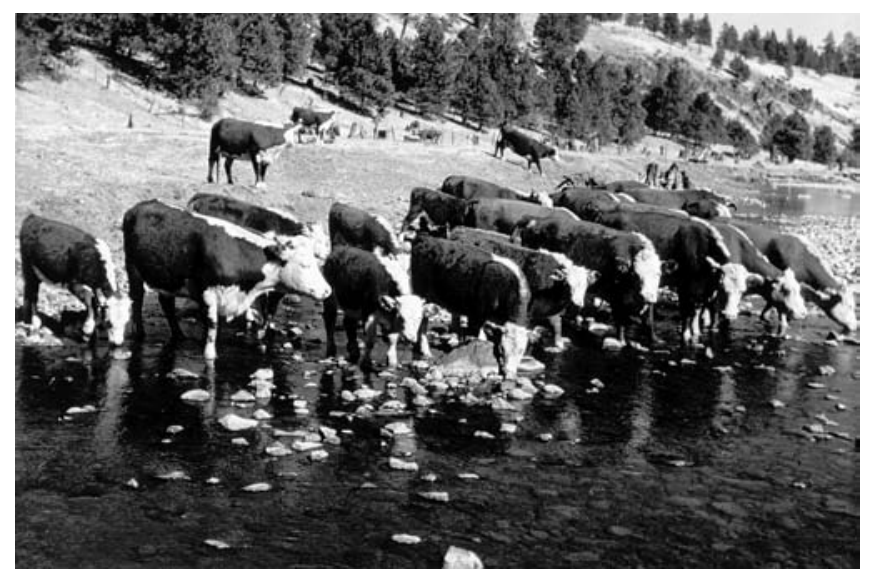

Typical riparian area on Starkey Experimental Forest and Range in 1952. Photo courtesy of Robert Harris.

or catastrophe, to galvanize enough opinions to push the majority of the population to a new value set. Things like floods, fires, wars, and economic collapse can cause values to galvanize and policies to shift quickly. Things like large clear-cutting, overgrazing, and habitat degradation take a longer time to cause the weight of evidence to shift for a majority of the public.

\section{Settlement and Exploitation-Before 1905}

Before 1905, America was settling the vast frontier and building a nation. Society's values were interpreted and implemented with results mostly focused on exploitation and expansion of settlement into the West. Timber and rangelands were seen as a "never ending resource." The outcome was clear-cutting trees to make way for agriculture and development, deforestation, flooding, mining for resource extraction, overgrazing, and range wars. With increasing populations in the West, large fires were becoming more of a public issue. The battle of the open range was largely fought during this period. Overgrazing in the mountains of Utah was so rampant that floods and debris flows were blamed in large part on a lack of vegetation. Conservation of resources for future use was a concept that was present but neither widely understood nor valued. Laws and policies were largely centered on disposal of public land and exploitation of resources for economic purposes. Many of the outcomes of these policies were the exact issues that drove early conservationists to press for forest reserves and national parks.

\section{Conservation and Regulation-1905 to 1960}

Forest reserves and national parks were viewed as essential to protecting the public interest in natural resources. In 1905 the Forest Service was created to manage 63 million acres with 500 employees. For the first time, federal forest lands were viewed as assets for society rather than as lands waiting for disposal to private interests. Conservation was in the public view, with Congress and the President taking direct action. The mission of the fledgling Forest Service can be

\section{Roads, Roads, and More Roads}

When I worked in Colorado in the 1970s as an assistant ranger, I saw what was proposed by the assistant ranger for timber and recreation as the ultimate road network. It had all nonwilderness, forested areas on the district roaded so that no area was more than one-fourth mile from a road. It literally made the forest look like a patchwork of herringbone material. I thought that proposal for roads was over the top, but most in the agency did not. Shifting values demonstrate that this concept would never be proposed today.

summarized as providing "the greatest good for the greatest number for the long run." Grazing allotments were created, permits issued, and regulations established. Managing these lands for multiple use was expected. Gaining control of abuse of the public resource was initially considered a primary role for the Forest Service.

The "Use Book" of 1905, written by Gifford Pinchot, dictated the purposes of the national forests, established the initial regulations for the Forest Service, and essentially proclaimed the agency values. The purpose of the national forests included: a perpetual supply of timber; flow of streams; prevention of unnecessary forest fires; prevention of decreases in summer carrying capacity of range; conservation and wise use of water, wood, and forage; decision of local questions locally; devotion of land to its most productive use; and achievement of the greatest good for the greatest number in the long run.

The life of an early Ranger was focused on fulfilling the vision of the agency through personal work. In a letter dated July 10, 1915, the Rangers of the La Sal National Forest in Utah were given marching orders: "There is a great deal of work to be done on the forest, such as improvement of Stations, trail, drift fence and telephone line construction, maintenance of Ranger pastures, posting of signs, and many

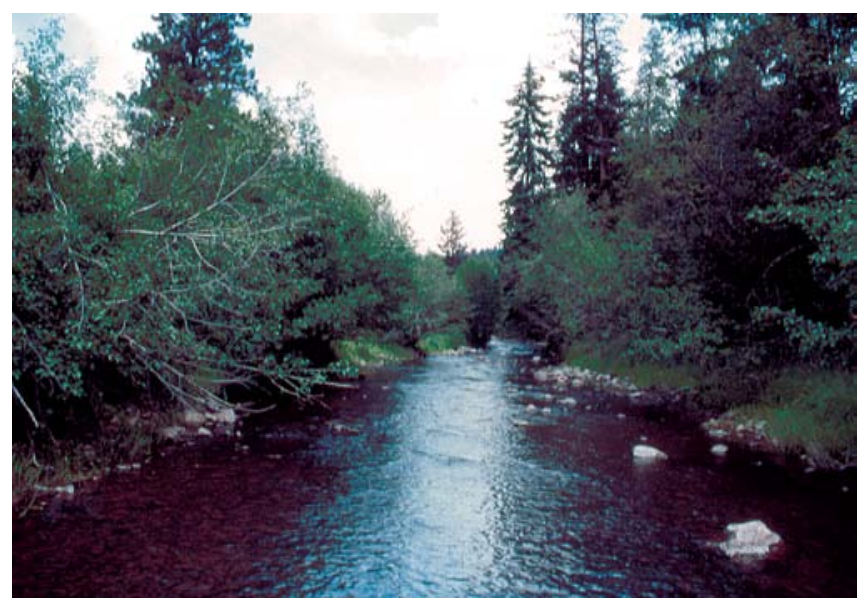

Typical riparian area on Starkey Experimental Forest and Range in 1995. Photo courtesy of USDA Forest Service. 
other things." The letter goes on to describe how Rangers were expected to work hard and should not be sitting around the Ranger Station reading or otherwise engaged in nonproductive work. The Ranger was the "doer" in those days. The 1905 "Use Book" specifically stated that the Ranger was expected to endure hardship and perform severe labor under trying conditions. "Invalids seeking light out-of-door employment need not apply." There were no large crews to be supervised and rangers were expected to furnish their own stock and have no side occupations. Being a Ranger was considered a 24-hour-a-day commitment. The commitment extended to the spouse of the Ranger who typically minded the Ranger Station in the Ranger's absence.

Grazing receipts exceeded or equaled timber receipts until 1921. Greeley's 1955 book on the Forest Service reported that range problems constituted the bulk of the forester's daily tasks. Overgrazing was rampant. Gaining control of livestock use was a major thrust of the agency from its inception. Range surveys and range allotment plans focused on improving range conditions while remaining committed to providing livestock grazing use. Drive trails on Western forests were used to move millions of sheep from lower elevation winter ranges to higher elevation summer ranges. Many of those driveways today are identifiable for their erosion pavement and early seral vegetation.

Riparian areas were noted for their lack of vegetation. The concept of sacrifice areas, or areas in which overgrazing was to be expected, was deemed acceptable. In fact, it was a step forward in the progression of commitments to begin recovery of much of the Western rangeland.

Small rural towns used to expect cattle drives down the main street. Being stopped on a highway because sheep were trailing toward summer range was a common occurrence in rural settings. Those activities and scenes are now rare.

The 1960s introduced an era in which range managers and agency policy makers believed we could manage national forests to meet all demands. On the timber side, programs and studies were put in place in an attempt to maximize pro-

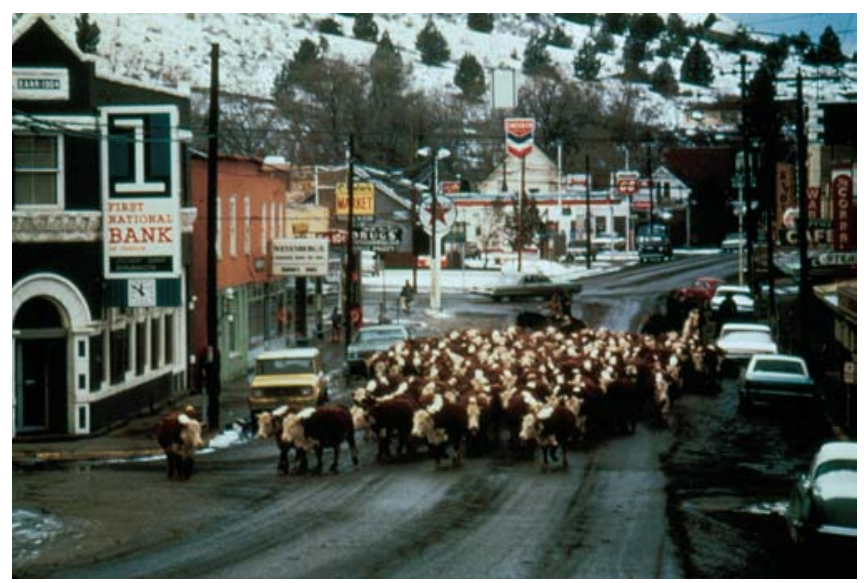

Cattle drive through downtown John Day, Oregon. Photo courtesy of USDA Forest Service.

\section{The Generation Gap}

While my Dad was a District Ranger and I was an Assistant Ranger, I took my Dad with me to do range survey work on an allotment at an elevation of nearly 11,000 feet in Colorado. At lunch, we took a break and leaned back against a big old spruce tree. My Dad said, "These big old trees make my finger itch. Where's the chain saw? These trees aren't doing anyone any good just standing here." I had thought all along that my Dad and I shared the same conservation ethic and values. It was then that I realized my values were indeed different than my Dad's. That tree was at least 200 years old and would take that long to replace. It did not make sense to me that we might cut that area to provide wood. To my Dad those trees were wasted if they were not "used."

duction. This was the era of the regulated forest: Clear cutting was the dominant harvest strategy, thinning to increase growth and production was emphasized, and road building to gain access to old growth timber made the Forest Service engineering staff one of the largest road-building organizations in the world. The Forest Service was convinced that society wanted managed forests. On rangelands, management was designed to maximize the production of red meat to fulfill society's demands. Crested wheatgrass seedings, sagebrush eradication, juniper chaining, and brush control were undertaken on large tracts to increase forage production and eliminate poisonous plants like halogeton. Campgrounds were greatly expanded - the new roads created primarily for timber purposes provided access to areas previously not accessible. States transplanted wildlife to meet hunter demands and to return wildlife to areas that were recovering from prior abuse. Fish hatcheries were introduced to meet the demands for fishing across the West. Laws passed during this period emphasized multiple uses (Multiple Use Sustained Yield Act), planning to meet society demands (Resources Planning Act), and the creation of wilderness areas (Wilderness Act).

In the broad sense, there were no large outcries from the public to stop putting forward visions of the managed forest to meet society's demands. That outcry slowly grew, but it took several years to accumulate sufficient weight of evidence to convince Congress and the courts that change needed to occur. Laws were forthcoming, but a significant lag occurred.

\section{The Planning Era-1976 to 1993}

With the passage of the Forest and Rangeland Renewable Resources Planning Act of 1974 and the National Forest Management Act of 1976, the reality of the National Environmental Policy Act of 1970 and the Endangered Species Act of 1973 took hold of the Forest Service. This era is marked with massive investments in forest planning. Interdisciplinary teams were formed to plan the future uses 
of the national forests. Nearly every forest hired economists and more wildlife and fisheries biologists to move the planning forward. Optimization models were developed for virtually every forest, with joint maximization of timber, range, and wildlife as the objective function. The planning regulations introduced the concept of species viability, a concept that, when coupled with the Endangered Species Act, became the primary driver of change in forest management during the 1990s. Downward pressure on livestock grazing continued on much of the Western rangeland during this period. Investment in research on rangelands was substantial. The number of range scientists focusing on Western rangeland issues peaked during this period. For example, in 1985 there were 22 range scientists in Forest Service Research; in 2005 there is just one. Large rangeland investments were undertaken in efforts to maintain stocking rates through increased forage production. The Oregon Range Evaluation Project was launched in 1976 as a 10 -year, $\$ 10$ million investment in response to a national Red Meat Initiative. The stated intent was to determine whether the grazing strategies that were used in the national projection of red meat production were correct. It was assumed that society would be willing to invest federal funds in intensive grazing strategies to meet the demand for red meat.

In 1986, the Forest Service re-evaluated its core values. The Forest Service proclaimed its values to be summarized in the phrase "caring for the land and serving people." Its precepts were to care for healthy ecosystems, have a professional and diverse workforce, care for future generations, and be responsive to the public. Public sentiment was beginning to be more strongly stated regarding intensive use of public forests and rangelands for private gain. The weight of evidence grew substantially stronger, suggesting that wildlife, water, and recreation were beginning to nudge out forage and timber as the highest and best use of the national forests and grasslands.

\section{Ecosystem Management and Gridlock-1993 to 2004}

Lawsuits over endangered species habitats resulted in a virtual gridlock of Forest Service timber actions in the Northwest. A new set of issues began to dominate the public discussion, with 1993 being a watershed event in the policies of the Forest Service. In 1993, President Clinton announced the Northwest Forest Plan addressing the Northern Spotted Owl, old-growth timber, and anadromous fish. Ecosystem management, biodiversity, species viability, and endangered species issues dominated much of the policy debate and planning efforts. Large-scale regional assessments were launched in the Northwest, Interior Columbia Basin, and California Sierra Nevada mountains. Emphasis was quickly removed from optimization solutions to largescale planning efforts. More energy was directed toward simulating the future under varying strategies for managing integrated ecosystems rather than maximizing outputs. The emphasis was on projections of what might be possible while maintaining viable populations of fish and wildlife. Following the implementation of the Northwest Forest Plan, harvest of timber in the Northwest declined precipitously, over $75 \%$. The reliance of counties on receipts from timber sales on federal land was replaced by economic initiatives. Counties with substantial lands in federal timber could no longer rely on receipts from timber sales.

A century ago, the nation was committed to protecting water, ensuring sustainable forests, controlling nonpermitted uses, and assuring that wise use was exercised on the Nation's forests. These values overlap with those articulated in the first "Use Book" of the agency but also differ in some significant ways. In 2004 the Forest Service's proclaimed values are articulated in its goals and mission statement. The stated mission of the USDA Forest Service is to sustain the health, diversity, and productivity of the Nation's forests and grasslands to meet the needs of present and future generations. The primary goals include: reduce the risk from catastrophic wildland fire, reduce the impacts from invasive species, provide outdoor recreation opportunities, help meet the Nation's energy resource needs, and improve watershed conditions. The simple claim of providing the greatest good for the greatest number in the long term remains an underlying theme the agency retains but articulates what that means in today's world differently than it did a century ago.

A rare data set exists that compares values for the multiple use categories through time for Forest Service employees and leadership. In 1989 Jim Kennedy and I undertook one of the first studies of Forest Service values. This study examined whether Forest Service employees 1) actually supported caring for the land and serving people values stated in the 1986 vision statement and 2) believed the agency reward system encouraged employees to follow these vision statement values. The survey was essentially repeated 15 years later, in 2004. Line officers, those with primary decision authority, perceived in 1989 and 2004 that the public values wildlife, water, and recreation higher than it values wood and grazing (Fig. 2). The lowest value was perceived to be associated with grazing.

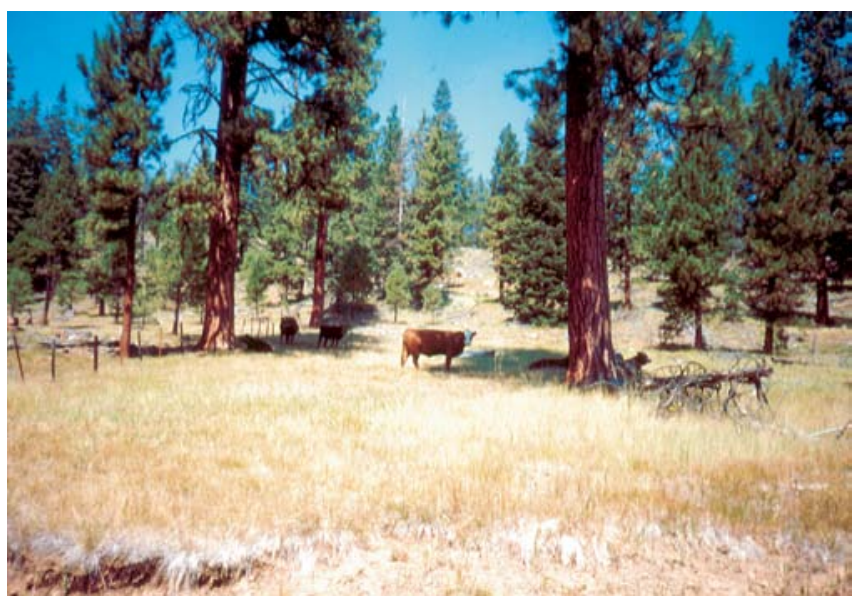

Ecosystem services and resource use could drive future management decisions. Photo courtesy of Marty Vavra. 


\section{How Line Officers Believed the Public Ranked Multiple Use Values, 2004 and 1989}

\section{$2004 \square 1989$}

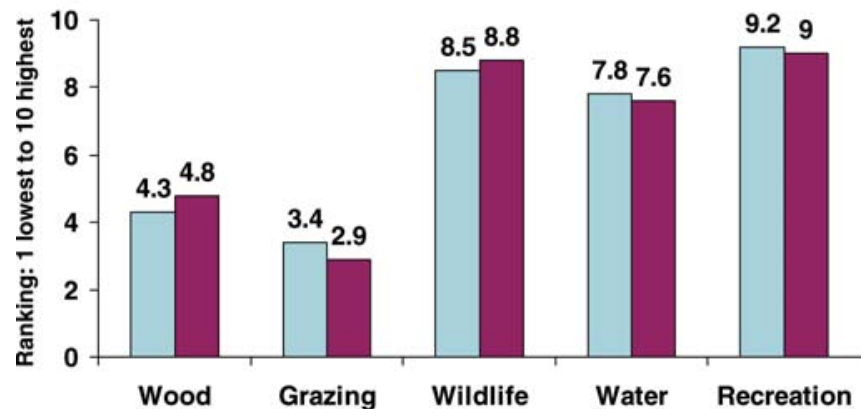

Figure 2. How Forest Service line officers ranked the multiple uses of wood, grazing, wildlife, water, and recreation on a scale between 10 (high) and 1 (low) in 1989 and 2004.

When asked how these line officers believed the Forest Service ranks the multiple uses, in 1989 there was a belief that wood was more highly valued by the agency than the other multiple uses. If this were true, it would be reflected in the budgets, policies, and emphasis at all levels in the agency. When asked the same question in 2004, line officers believed the Forest Service ranks all the multiple uses at nearly the same level, showing a substantial decline in how the agency ranked wood relative to the other uses. This shows a substantial difference still exists between how the line officers perceived the public values and how the agency ranks the public values (Fig. 3).

When asked how the line officers personally ranked the multiple use values, there is considerably more alignment with how they perceived public values than with how they perceived the agency values the multiple uses. There are no substantial shifts between the 1989 rankings and the 2004 rankings for how line officers personally ranked the multiple use values (Fig. 4).

Newer terminology might have overtaken some of the ways the Nation expresses its values about its forests and rangelands. When compared across the perceptions of how line officers believed the Forest Service values, how the public values, and how they personally value these newer outputs, similar trends continue to express themselves (Fig. 5). The Agency and line officers are perceived to value fuels management higher than other outputs, whereas the public is perceived to value landscape beauty above the other outputs. The public is viewed as having lower values for vegetation management and biodiversity than for landscape beauty and fuels management. The Agency is viewed as valuing fuels management and vegetation management above biodiversity and landscape beauty. These contrasts undoubtedly play out in debates about management direction, priorities for action, and policies at all levels. The lag between public values and agency values is persistent and predictable. When does the weight of evidence become compelling enough to shift to new policies, laws, and priorities? One cannot predict

\section{Thanks...But I Don't Need Your Help}

When driving down the Columbia Gorge to make a presentation to a class at Oregon State University, I pulled up behind a car going 65 miles an hour. It was obvious that the car had a flat tire. It was not yet flapping but it was about to. I pulled alongside the car and waved and motioned that the car had a flat. The driver would not look my way or acknowledge that I even existed. I could see this was not going to work. I backed off and scribbled on a note pad "FLAT TIRE". I then drove by the car while holding up the note, but not looking at the driver. After I passed the car, the driver pulled over. I stopped to see if I could help. The driver would not roll down the window, but got on a cell phone and motioned me to go on.

While $\mathrm{I}$, as a scientist, may see that a wreck may be just around the bend, the user might not be interested in hearing my story. Scientists make observations that sometimes result in them shouting and waving their arms about in an attempt to get someone's attention that problems are heading our way. Sometimes the scientist or science gets ignored. Even after the recognition that a problem is indeed around the corner, managers or society might say they will take care of it alone. "Thank you very much but I don't need your help." Sometimes science gets it wrong and there really is no flat tire. Perhaps the tire was a specially build test tire and this was just a test to which the driver had full knowledge. Sometimes there are scientists waving their arms that we need to go right to avoid disaster at the same time that other scientists are waving their arms that we need to go left to avoid disaster and still others are saying to stay the course or disaster will happen. Science credibility is on the line with each shout. In the end, the only thing science has to peddle is its credibility.

when, but there are circumstances that cause the weight of evidence to shift dramatically and could result in shifting policies and priorities.

\section{How Line Officers Believed the USDA Forest Service Ranked Multiple Use Values, 2004 and 1989}

\section{$2004 \square 1989$}

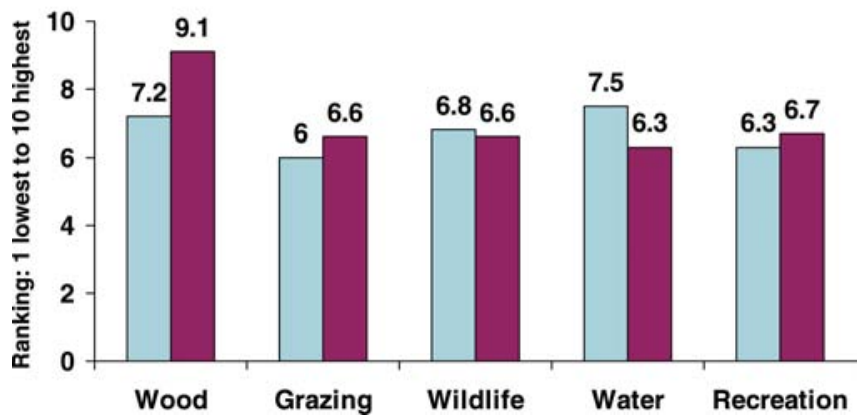

Figure 3. How Forest Service line officers believed the agency ranked the multiple uses in 1989 and 2004 on a scale between 10 (high) and 1 (low). 
How Line Officers Personally Ranked Multiple Use Values, 2004 and 1989

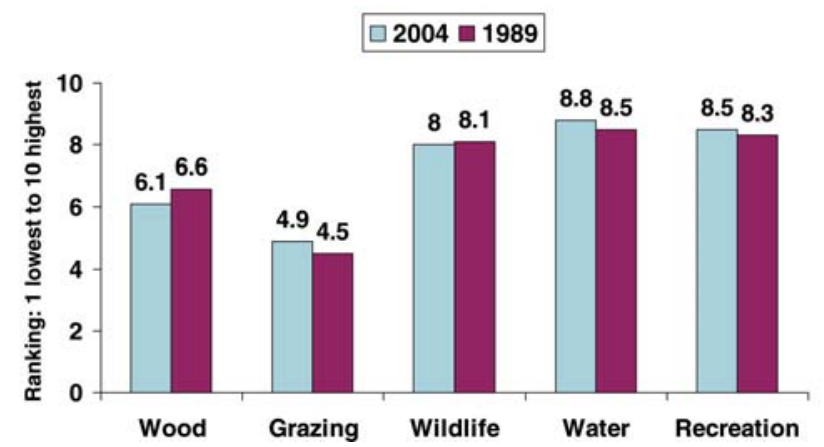

Figure 4. How Forest Service line officers personally ranked the multiple uses in 1989 and 2004 on a scale between 10 (high) and 1 (low).

When asked what the Forest Service should reward, three elements consistently received $50 \%$ or higher support from line officers in both the 1989 and 2004 surveys. These included care for ecosystems, professional competence, and building consensus. Dropping from this high level of overlap were care for the development of employees, care for future generations' needs, and being innovative and a risk taker. New issues have pressed their way into the debate and perceptions of line officers. Establishing a consistent set of reward systems that encourages the achievement of the Agency mission and goals is a dynamic process. In 1989, there was not a national strategic plan for the Forest Service. Now, thanks partly to the Government Performance and Results Act of 1993, there is pressure within all federal agencies to link an accountability system to the strategic goals, investments, outputs, and outcomes that are sought by society. A formal process is shaping up to make this linkage a performance accountability system. Perhaps the narrowing of values the Agency should reward is a reflection of this migration from independence across the National Forests to accountability to national goals.

\section{What is the Role for Science?}

The Forest Service has one of the world's largest natural resources research and science organizations. The agency has moved more and more toward what is referred to as sciencebased decisions. Although the decisions appropriately remain in the domain of the Resource Manager, scientists are being called on more and more to offer information pertinent to the decision-making process. Although science remains a primary means for advancing our understanding, it also is appropriately engaged in assessing resource conditions, critically evaluating options managers propose, documenting findings from studies, and transferring technologies into applications useful to managers. New planning rules recently published by the agency call for the use of best available science in its decision making. In its application, this should not result in sci- entists becoming decision makers but should result in transparent expressions of how, and what, science was used in decision making. Scientists should be better able to understand managers' needs and better target studies aimed specifically at gaps in understanding or toward tools that will make decision making more efficient and effective.

\section{The Future-2005 to??}

In a recent discussion about global forestry issues that are dominated by concerns of sustainable development, I was interested to learn that many of the lesser developed countries are finding solutions to deforestation and fire through community-based forestry approaches. In this context, contractors are not used to oversee the extraction of federal timber and contain fires. Rather, local communities are given the responsibility, and the ensuing benefits, of managing the local forest resources. In that process, local solutions that have local benefits are found to problems, local workers are employed in getting the work accomplished, and local communities decide where, how, and to what extent timber extraction will occur. The result has been a substantial reduction in deforestation; in fact, many of these community forest operations have become certified internationally as practicing sustainable forestry approaches to management and reduction in wildfire. Are there lessons that might be drawn from the solution to these international problems?

There is increasing recognition that fire, invasive species, development (subdividing ranch parcels or forests), and unregulated recreational uses pose real threats to the Nation's forests and rangelands. As ranching becomes less profitable, there is increased pressure to sell the property to developers, thus further fragmenting habitats and resources. What are the incentives to retain private land in an undeveloped state? There is a growing interest in the potential for incentives on wild land to provide ecosystem services. Although no market currently exists to capture revenue from these elements, perhaps markets could develop to enable local communities and individuals to benefit from managing lands to provide a complement of ecosystem services, including the capture and storage of carbon to assist in global climate issues, to provide clean water to a growing population, to reduce the risk of

\section{Newer, Post Industrial National Forest "Outputs" or Achievements, 2004}

\begin{tabular}{|l|c|c|c|}
\hline $\begin{array}{l}\text { Post-Industrial } \\
\text { "Outputs" }\end{array}$ & $\begin{array}{c}\text { How USDA } \\
\text { FOREST } \\
\text { SERVICE Values }\end{array}$ & $\begin{array}{c}\text { How PUBLIC } \\
\text { Values }\end{array}$ & $\begin{array}{c}\text { My PERSONAL } \\
\text { Values }\end{array}$ \\
\hline Landscape Beauty & 6.4 & 8.5 & 7.6 \\
\hline Biodiversity & 6.7 & 5.9 & 7.7 \\
\hline Fuels-Mgmt & 8.7 & 7.1 & 8.6 \\
\hline Vegetation-Mgmt & 7.9 & 5.3 & 8.3 \\
\hline
\end{tabular}

Figure 5. How Forest Service line officers believed the agency, the public, and they personally valued newer outputs or achievements in 2004 on a scale between 10 (high) and 1 (low). 
catastrophic fire, and to meet biodiversity goals expressed in the Endangered Species Act.

A sustainable society and natural resources are a clear goal, yet how to achieve an integration of social, economic, and ecological goals remains elusive. The challenge of the next decade and beyond will be to find working solutions to this integration on rangelands, forestlands, and agricultural lands. A part of that job will include determining where and how to use active management to produce goods and services but also to restore ecosystems to provide the ecosystems services we will depend on. Science can help us understand the options, consequences of various actions, and tradeoffs associated with the choices. In the end, as values continue to shift and evolve, policies and laws will appear out of sync with societal values as it plays its never-ending catch-up game of constantly examining the weight of evidence about society's values.

The values in real estate are based largely on "location, location, and location." The values in natural resources are largely dictated by "purpose, purpose, and purpose." It is the expression of that purpose that is constantly in flux and creates so many interesting discussions and debates.

Congress in its wisdom has not unambiguously dictated the purposes for active management on the national forests and grasslands. Rather, there are historical laws that lay out conflicting purposes and new laws that dictate what process to use when planning and implementing management actions. Consequently, agency personnel are left essentially to judge what values should be emphasized and what changes to implement. Groups or individuals who take exception to the process or proposed outcome can, and do, file lawsuits against the agency for the proposed action. The recipe is clear, the Forest Service proposes action and gets sued. If the Agency loses the suit, it pays the costs incurred by the litigants. This cycle perpetuates more lawsuits. If no clear purpose is going to be forthcoming from Congress, then the agencies are left with trying their best to walk the "process" from proposed action to proposed action. The controversy is not likely to be settled by administrative action supported by strong statements of purpose in the law. Thus, the precautionary principle becomes the watchword and its interpretation seems to ignore the reality that the "no action" alternative bears significant risk. This leaves us with the question of whether the forests and rangelands of today are sustainable.

What does it take to pass clear legislation for agency action? The debate about active management to reduce fire risk is a good example. The forest health debate took on real steam in the 1990s when fires and insect and disease epidemics began to change large landscapes rapidly. Although there was congressional interest expressed via hearings and press releases, no significant new funding or laws were passed until the fires of the late 1990s and early 2000s invigorated action on a comprehensive fire strategy pushed by the Western Governors. Legislation was proposed but not passed by both houses of Congress until the fires of Southern California became a nightly news spectacle. Millions of acres of forest and rangeland burned, thousands of homes were lost, and dozens of individuals died. Why should it take a crisis of this proportion to sufficiently motivate new legislation providing clear, unambiguous statements of purpose for active management? It appears that the Healthy Forest Restoration Act of 2003, coupled with large funding increases to implement the comprehensive strategy for fire and fuels, is motivating action and breaking gridlock.

Are there other crises on the horizon that might motivate a statement of clear purpose for the Nation's forests and rangeland? Or will the Forest Service be left to work its way through the bureaucratic process jungle and objective conflicted legislation? Only time will tell.

Although Marion Clawson's classic 1975 book asked the question "forests for whom and for what?" We only need to slightly rephrase the question, "sustainability for whom and for what?"

Author is Director, Pacific Northwest Research Station, USDA Forest Service, Portland, OR 97204. This paper is adopted from a presentation at the Centennial Forum sponsored by the Rocky Mountain Region and Rocky Mountain Research Station of the USDA Forest Service in Fort Collins, Colorado, November 2004.

\section{Additional Reading}

Cramer, L. A., J. J. Kennedy, R. S. Krannich, and T. M. QUIGLEY. 1993. Changing forest service values and their implications for land management decisions affecting resource dependent communities. Rural Sociology 58(3):475-491.

Kennedy, J. J., R. W. Haynes, And X. ZHOU. 2005. Line officers' views on stated USDA Forest Service values and the agency reward system. Portland, OR: U.S. Department of Agriculture, Forest Service, Pacific Northwest Research Station. General Technical Report PNW GTR-632. 72 p.

Kennedy, J. J., AND T. M. Quigley. 1998. Evolution of USDA Forest Service organizational culture and adaptation issues in embracing an ecosystem management paradigm. International Journal of Landscape Ecology, Landscape Planning and Landscape Design 40:113-122.

Miller, C. 2001. Gifford Pinchot and the making of modern environmentalism. Washington, DC: Island Press. 458 p.

Pinchot, G. 1905. The use of the National Forest Reserves-regulations and instructions. U.S. Department of Agriculture, Forest Service. 142 p.

QUIGLEY, T. M. 1989. Value shifts in multiple use products from rangelands. Rangelands 11(6):275-279. 